\title{
Qatar's Educational Reform: The Experiences and Perceptions of Principals, Teachers and Parents
}

\author{
Michael H. Romanowski ${ }^{1, *}$, Maha Ellili Cherif ${ }^{1}$, Badria Al Ammari ${ }^{1}$ \& Asma Al \\ Attiyah $^{2}$ \\ ${ }^{1}$ Department of Educational Sciences, Qatar University, PO Box 2713, Doha, Qatar \\ ${ }^{2}$ Department of Psychology Sciences, Qatar University, PO Box 2713, Doha, Qatar \\ *Corresponding author: Department of Educational Sciences, Qatar University, PO Box 2713, \\ Doha, Qatar. Tel: 974-4403-5142 E-mail: michaelhr@qu.edu.qa
}

Received: July 12, 2013 Accepted: August 16, 2013 Published: August 20, 2013

doi:10.5296/ije.v5i3.3995 URL: http://dx.doi.org/10.5296/ije.v5i3.3995

\begin{abstract}
This study describes the implications of the massive Qatari educational reform, Education For a New Era (EFNE), from the perspectives of teachers, principals, and parents provides insight into these stakeholders perceptions regarding how EFNE has impacted teaching and learning and the new challenges they face. This qualitative study uses open-ended questionnaires, focus groups and interviews. Survey data is collected from 18 Independent Schools including 17 principals, 413 teachers and 565 parents and interviews with 17 principals, 26 teachers and 50 parents. Findings describe the effects, impact, the challenges and the advantages and disadvantages of EFNE on these stakeholders.
\end{abstract}

Keywords: educational reform; stakeholders; qualitative research 


\section{Introduction}

In 2001, Qatar's educational system came under great scrutiny. The government was concerned that the current educational system and structure in Qatar were "not producing high-quality outcomes" as benchmarked by international league tables (for example, Trends in International Mathematics and Science Study (TIMMS) and the Program for International Student Assessment (PISA) (Brewer, et. al., 2007, p. iii). Responding to this educational crisis, RAND, a nonprofit research organization was hired to provide a critical analysis of Qatar's K-12 education system. Findings from the analysis quickly demonstrated that the current Qatari educational system was “rigid, outdated, and resistant to reform” (Brewer, et. al., 2007, p. iii). RAND was requested to not only provide assessments but also recommendations that would bring about an educational system that addresses the country's changing needs.

The assessment pointed to several extensive weaknesses in the current educational system and structure. First, it was revealed that the current Qatari educational system lacked a vision of quality education and the needed support structures. The existing system was highly centralized, lacked performance indicators, and the little performance data given to schools provide limited potential since administrators and teachers had no authority to make changes (Brewer et. al, 2007). Second, the curriculum "was outmoded, under the rigid control of the Ministry of Education, and unchallenging, and it emphasized rote memorization” (Brewer, 2007, p. xviii). Third, there was a lack of communication and shared vision among educational stakeholders attributable, in part at least, to a top-down decision-making policy. Finally, little finances were directed to education evidenced by teachers' low pay, little professional development and the poor conditions of many school buildings and classrooms.

Qatar officials already knew most of the existing weaknesses and there was an awareness of previous unsuccessful attempts to reform the educational system. Thus any current reform required a major system-changing rather than incremental approaches and a clear implementation plan. With that in mind, recommendations offered four system-changing options. The Qatari government elected to support a charter school model that decentralizes education and encourages the development of Independent schools. As a result, a systematic reform designed to transform Qatar's schools and Ministry of Education into a world-class competitive education system, known as Education for a New Era (EFNE), was initiated (Brewer, et al., 2007).

EFNE is grounded in four principles: 1) autonomy for schools, 2) accountability through a comprehensive assessment system, 3) variety in schooling alternatives, and 4) choice for parents, teachers, and school operators. These principles represent a two-pronged approach to reform that requires the establishment of government-funded Independent schools over a multi-year period, and the implementation of annual assessments to measure student learning and school performance (Supreme Education Council, 2011a). The first cohort of Independent schools, consisting of 12 schools, opened in 2004 with the goal of turning Qatar's vision of developing a world-class education system into a reality. Today, all government-funded schools in Qatar have acquired independent status. Currently, there are 
over 170 Independent Schools operating in Qatar.

In order to ensure a successful implementation of the educational reform, the Supreme Education Council (SEC) was established and plays a vital role of quality assurance by ensuring that schools and teachers are performing according to high standards. The SEC directly supports Independent Schools and is responsible for setting curriculum standards and broad goals for the school system, providing professional development for teachers and school leaders, and conducting evaluation of schools performance and student progress.

During the decade of EFNE, there are many changes and adjustments made by the SEC. One of the major changes occurred in September 2011 when Independent School shifted from English as the medium of instruction to a bilingual approach for two subjects, math and science. Prior to this shift, cohort seven and eight Independent schools were already using a bilingual approach as the medium of instruction while cohorts one through six taught most classes in English. The curriculum, resources, planning, curriculum standards and students' textbooks were in English that proved problematic in numerous ways. EFNE has raised many questions and concerns but little research has been conducted on the stakeholders' perceptions of EFNE. In what follows, we examine Qatar's EFNE by presenting the perceptions of principals, teachers and parents who are directly affected by and involved in the reform. In particular, we are concerned with the challenges, advantages and disadvantages of the reform and the impact it has on those stakeholders.

\section{Stakeholders and Education Reform}

There is little doubt that the assessment of an educational system and the development of recommendations is a difficult task, however, most of this is on the theoretical level impacting few. However, the real challenge lies in the implementation of the reform moving from the theoretical to the practical level directly impacted stakeholders. More importantly, understanding the local context become vital during implementation. Fullan (2000) argues the main reason that educational reforms never fully develop and endure, is that reforms fail to understand the local school development. All large-scale change is implemented locally and the only way that change happens is through the effective daily implementation by principals, teachers, parents and students (Fullan \& Miles, 1992). Thus, these stakeholders are vitally important for the success and endurance of any educational reform effort. Because principals, teachers and parents play a crucial role in the implementation of reform, it is important to explore their experiences and obtain from them their opinions about the reform and accompanying changes. If educational reform is about providing local answers to educational questions, then widespread participation of among stakeholders is a requirement (Healey \& DeStefano, 1997).

One key stakeholder that holds a significant role in successful educational reform is the school principal. The majority of research studies on school effectiveness demonstrate that both in the primary and secondary schools, leadership is the key factor in successful reform (Leithwood, Louis, Anderson \& Wahlstrom, 2004; Sammons, 1999). When educational 
reform is initiated, principals must reframe their roles and shift their orientations in order to successfully implement reform (Fullan 2000). This is particularly true when schools are facing massive reforms. Those reforms that prove successful have strong supportive leadership, especially principals who motivates staff, parents and students to deal with and overcome uncertainty and embrace the change process (Matthews and Crow, 2003; Fullan; 2001; Leithwood, et. al, 2004; Kirk \& Jones, 2004; Houston, 1998). It is clear that principals are at the center for implementing change initiatives within the school and the principal's leadership also shapes the school climate regarding how teachers, parents, and students perceive reform and this is vital for the successful change. However, educational reform is demanding and reform presents principals with new challenges and to perform new roles that require different skills and attitudes (Newmann \& Wehlage, 1995). Thus, there is a need to examine the effects of reform on principals and investigate ways they can be supported as they strive to implement educational change.

Although the role of the principal is important in the implementation of educational reform, researchers argue that teachers role in educational reform may be more important to a successful reform (Margolis \& Nagel, 2006; Nunan, 2003; Bailey, 2000; Rea-Dickens \& Germaine 1998; Lieberman, 1997). The realization of educational reform is determined by teachers' acceptance, involvement in and their degree of ownership of the reform (Carless, 2001; Markee, 1997). Teachers are change agents that are vital for educational reform because reform requires, at times, major changes. Because the experiences of teachers enable them to understand the realities of communities, schools and classrooms, they can provide a unique perspective that differs from that of decision makers and bureaucrats. Teachers can provide valuable insight and suggestions regarding what will or will not work.

The key concern about educational reform is school changes ultimately rely on teachers (Lieberman \& Pointer-Mace, 2008; Spillane, 1999; Fullan \& Miles, 1992). Hargreaves and Goodson (1996) argue that most of the time educational reforms are a top-down process and is often the case, top-down reforms not only silences teachers' voices but also hampers reform. Mandated reforms seldom consider input from grassroots educators and do not reflect the importance of educators as professionals capable of making decisions that can benefit the parents and students they serve (Schweisfurth, 2002). Darling-Hammond (1997) argues prescriptive policies that are created without teacher input greatly reduce the school's ability to meet the needs of students and parents. Teachers are the key to educational reform and change and leadership that does not include teachers in the process of change is destined to fail (Fullan, 2011; Hargreaves \& Fullan, 1996).

However, a fundamental problem is that teachers' perspectives have great value for educational reformers and reform yet "teachers' perspectives have been a missing factor in the development of innovations ... the content and process of change are typically not in the hands of practitioners; change is assumed to be possible without their expertise, and their perspectives on change are frequently ignored” (Bailey, 2000, p. 112), thus hampering educational reform and creating resistance in some teachers. Researchers clearly point out that teachers are central to educational reform and successful implementation of educational change requires teachers to be fundamentally and meaningfully involved throughout the 
reform process (Kilgallon, Maloney, \& Lock, 2008; Brewer, et. al., 2007; Hargreaves, Earl, Moore \& Manning, 2001). Therefore, it is important to consider their perspectives when introducing change (Troudi \& Alwan, 2010; Lamie, 2005; Kirk \& Macdonald, 2001). Nevertheless, teachers are seldom included in either the development of reform or the assessment of the implementation.

Not only are teachers excluded but also parents lack a meaningful voice in the reform process although parents are one of the most important stakeholders in any educational reform (Adams \& O’Neil, 2010). Parental involvement in schools has been documented as academically beneficial by educational researchers and valued by many educators (Gonzalez-DeHass \& Willems, 2003). When reform is implemented, students are directly affected and parents play a vital role in helping their children as they adapt to change. Furthermore, parents can often see the strengths and weaknesses of schools and should be encouraged to offer their perspective (Matthews \& Crow, 2003). Still few reform efforts have made serious attempts to directly include parents (Lewis \& Henderson, 1997). Fullan (2005) argues that teachers and principals must take the risks of engaging the experience of parents if reform is going to be successful. The degree of family involvement is one characteristic of high-performing schools (Henderson \& Mapp, 2002). Therefore, family involvement and collaboration are critical aspects of successful comprehensive school reform efforts (Henderson \& Mapp, 2002; Lewis \& Henderson, 1997) and educational policy makers would be wise to both involve and include parents as a major component of education reform as advocates and full participants.

\section{Qatari Context: Stakeholders, Principals and Teachers}

To contextualize this study, we will provide some demographics regarding the Independent schools that are examined in this study, principals and teachers in Independent schools and parents of students who attend these schools. According to the Supreme Education Council (2012a) "an Independent school is a government-funded school that is granted autonomy to carry out its educational mission and objectives while being held accountable to terms agreed to in an operating contract." Independent schools are segregated by gender and are broken into primary, preparatory and secondary schools for boys and girls. The 18 schools surveyed in this study were from Cohorts (Note 1) one, four and seven schools.

Each Independent school has an owner or operator and a principal. The number of assistant principals varies for each school based on a ratio of the number of students and there is a coordinator for the individual departments. The principals of all Independent schools must be Qatari and there is a wide range of educational backgrounds and experiences among the principals. All principals receive leadership development programs offered by the Supreme Education Council and can receive on-going training and support from the Supreme Education Council.

The majority of teachers in Independent schools are expatriates, mostly from other Arab countries. Independent school teachers enter the classroom with a wide range of educational 
backgrounds, many unqualified. According to the Supreme Education Council (2011), more than 30\% of teachers in Qatar are not qualified to teach; 31\% of teachers in Qatar have no formal qualifications to teach, 35\% of who are teaching in Independent schools. Although Qatar hopes to achieve 70\% Qatarization of teachers and staff in these schools in the near future, only $25 \%$ of teachers in Independent schools are Qataris.

There is also a great diversity of the parents who send their children to Independent schools. With a large expatriate population, in 2010 79.7\% of all residents were foreign citizens (Sambidge, 2010). Parents of students in Independent schools include Qatari citizens, resident expatriates (white-collar workers), and labor migrants (laborers or blue-collar workers). Regarding parents' view of Independent schools, The Social \& Economic Survey Research Institute (2011) reports that $49 \%$ of parents with a child enrolled in an Independent school would keep the child at the same school and only 39\% of parents who send the child to an Independent school were very satisfied.

\section{Research Methods and Design}

This paper examines teachers', school leaders' and parents' perceptions of the impact of EFNE and the Independent school model on teaching and learning in the Qatari educational context. More specifically, it explores the possible educational issues that have surfaced during this fast paced educational reform and seeks to gain insight into the stakeholders' perspectives regarding how far this charter-like movement is applicable to the Qatari educational situation. The research questions are as follows:

1. What are the effects of EFNE on principals, teachers, parents and students?

2. What is the impact of EFNE on principals, teachers, parents and students?

3. What are the challenges that these stakeholders face as a result of the reform?

4. What are the advantages and disadvantages of the Qatari school reform as perceived by principals, teachers and parents?

Regarding the exploratory nature of the study that seeks to investigate the stakeholders' perceptions, open-ended questions were more appropriate for the purposes of this research. While closed questions allow to collect data that can be analyzed statistically and yield generalizable results, the narrative comments from open-ended questions provide a forum for explanations, meanings and new ideas that allow to describe a phenomenon as it is lived and perceived by the respondents (Cohen, Manion \& Morisson, 2007). Coupled with semi-structured interviews with principals and parents and interviews and focus groups with teachers based on the emergent survey themes, this qualitative research study provides in-depth understandings regarding how stakeholders view EFNE by identifying and describing their perceptions.

For this study, researchers developed three questionnaires to examine stakeholders' experiences with EFNE and elicit information regarding the effects of EFNE, the challenges 
they face, the advantages and disadvantages of the reform and their opinion regarding the recent shift back to bilingual the language of instruction. The instruments were initially written in English then translated into Arabic and judged for the quality of the translations by bilingual native Arabic speakers. Face validity was obtained by having two bilingual professors who are well qualified in conducting research examine each questionnaire and determine if the questionnaire in the Arabic translation was accurately asking participants to explain the effects, impacts, advantages and disadvantages and challenges of the educational reform in Qatar.

Researchers and research assistants delivered the questionnaires to all participating schools. Principals will be asked to distribute to teachers and other administrators and to follow their plan to distribute questionnaires to parents. Dates were set to collect the questionnaires. We distributed one survey for the principal, 40 for teachers and 100 for parents. Each principal was given a deadline for the collection of the surveys (usually two - three weeks). In order to increase the return rate, several phone calls and visits were made to remind the principal or whoever was responsible for the surveys about the deadline. When a school did not achieve the desired return rate, we did extensive follow-up visits asking for the surveys to be returned. This proved effective and is demonstrated in the final return rates (see table 4.).

After the initial data analysis of the questionnaires from 18 schools, individual interviews were conducted with principals, teachers and parents. Several questions were developed from the themes of the questionnaires and used to guide the semi-structured interviews and focus groups. Interviews and focus groups were conducted in both schools that were surveyed and some that were not surveyed in order to develop a deeper understanding regarding some items on the questionnaire and to determine if the findings from the questionnaires were evident in other schools.

\subsection{Sample}

This research was conducted at 18 Qatari Independent Schools. These schools are Cohort one, four and seven schools and were chosen because of their tenure in the educational reform and represent a wide range of experience with EFNE. Cohort one schools have eight years experience, cohort four six years and cohort seven two years. Since the reform is evolving and changes occur frequently, it would be beneficial to hear the voices of both experienced and less experienced schools. The schools surveyed included six schools from each cohort (one, four and seven) with the following breakdown: two Primary Boys Schools, three Preparatory Boys Schools, four Secondary Boys Schools, four Primary Girls Schools, two Preparatory Girls Schools and three Secondary Girls Schools. Table 4.0 Illustrates the sample regarding the number of participants for surveys, the return rates and the number of participants that were interviewed. 
Table 4: Sampling and Return Rates

\begin{tabular}{llll}
\hline Participants & $\begin{array}{l}\text { Survey } \\
\text { Number }\end{array}$ & $\begin{array}{l}\text { Return } \\
\text { Rate }\end{array}$ & $\begin{array}{l}\text { Interview } \\
\text { Number }\end{array}$ \\
\hline Principals & 17 & $94 \%$ & 17 \\
Teachers & 413 & $57 \%$ & 26 \\
Parents & 565 & $31 \%$ & 50 \\
\hline
\end{tabular}

\subsection{Data Analysis}

A research assistant was hired who is bilingual in English and Arabic and has a Masters Degree in Education Curriculum and Instruction. She was responsible for the translation of all surveys. Upon completion of the translation, the questionnaire data was analyzed. Unlike quantitative research that is deductive and centers on the testing of theory, this study attempts to discover and generate emerging theory as described by participants and to look for variables in a particular situation that nobody has yet identified or studied. The newly discover theory will then be used to develop sound research based recommendations that could be implemented in these particular school settings.

In this study, Grounded Theory Methodology served as the research philosophy because it seeks to construct concepts and categories about issues of importance in peoples' lives (Strauss \& Corbin, 1998). The researcher approaches the situation with no a priori framework and has no preconceived ideas to prove or disprove. The aim is to develop concepts and theory that are grounded in the accounts and experiences of the participants. Grounded Theory Methodology allows the researcher to study a phenomenon without a set framework but instead lets the issues emerge (Kezar, 2005). This qualitative approach is characterized by an emphasis on describing, understanding, and explaining complex phenomena (Sofaer, 1999). Through interaction with survey data and interviews with teachers, principals and parents, issues emerge, categories are identified and relevant examples are used to support the data.

There is no easy way to analyze information produced in conversations among people. Bogdan and Biklen (2002) define qualitative data analysis as "working with data, organizing it, breaking it into manageable units, synthesizing it, searching for patterns, discovering what is important and what is to be learned, and deciding what you will tell others" (p. 145). The task is to develop complex meanings of the raw data. A conceptual content analysis was conducted in order to establish both the existence and frequency of particular concepts in the data. The responses were grouped according to each survey question. Responses to each open-ended question were examined in the context of the research questions and involved selecting, focusing, condensing, and transforming data guided by thinking about which data best answer the research questions. During the analysis, data was broken down and organized that facilitated identifying meaningful themes and patterns that helped answer the initial research questions. Data was coded and notes were recorded regarding the emerging themes were then content analyzed and relevant quotes were integrated into various themes in order to support or refute particular findings. The rationale was to provide an accurate account of 
the principals', teachers' and parents' perceptions of the educational reform Education for a New Era.

When the data was saturated, findings were discussed and it was decided that there was no need to survey additional schools. Based on the data analysis, semi-structured interviews were conducted based on questions developed form the emergent survey themes. Questions were designed to probe further the themes. Upon completion of the interviews, a conceptual content analysis was conducted in the same manner as described above using emerging themes and information to better answer each research question.

\section{Findings}

The results of the study are presented in three major sections each elaborating on a single group of stakeholders' perceptions including the data from questionnaires and knowledge gained from interviews and focus groups. First, the principals' perceptions are introduced followed by the teachers' and then the parents'. Each section focuses on the major themes that emerged from analysis of the responses of one group of stakeholders.

\subsection{Principals’ Perceptions}

Overall, principals in this study were positive regarding EFNE. Several viewed the reform as an important process needed to develop individuals, serve the needs of the country (economic, cultural and scientific) and keep abreast with changes in the world. These principals had concerns regarding the importance of English and decreased importance of Arabic, the abrupt way the reform was implemented, the effectiveness of the reform and the lack of principals and teachers involvement in the decision making regarding the reform. However, most principals were in agreement that reform results take time.

Specifically, the principals' questionnaire asked whether the reform led to changes in their roles as school leaders and leadership style, their perceived impact of the reform on teachers, students and the school as a whole, and the challenges that they and their schools face in the implementation of EFNE. The analysis of responses shows that one hundred percent of the principals agreed that EFNE influenced their role as principal arguing that their administrative role is becoming more complex and encompassing more varied types of activities. The principals indicated that they are responsible for more tasks like evaluating teacher performance, setting professional development programs and writing strategic plans. Nevertheless, it also challenges principals in various ways. In order to aid this discussion, Table 5.1 provides a brief overview of the principals’ survey and interview findings. 
Table 5.1. Brief Summary of Key Principals’ Findings

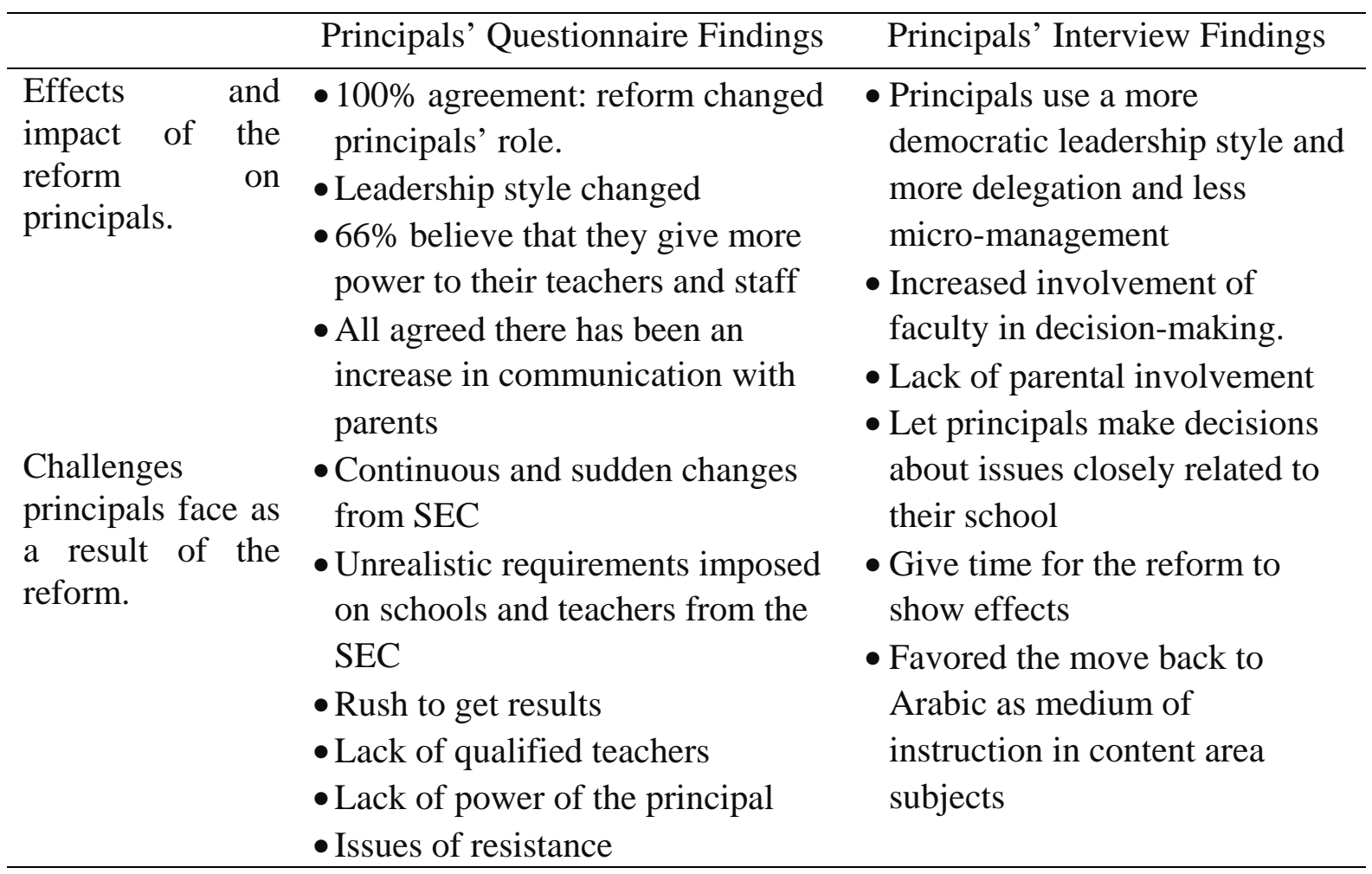

5.1.1 What are the effects and impact of EFNE on principals?

According to the questionnaire data collected from school principals, the general consensus is that the reform led to changes in principals' leadership styles in several ways. These changes centered on the delegation of responsibilities and a leadership style that focused on communication. One principal stated, "educational reform needs lots of strategies, the simplest one would be delegation to ensure that the work continues effectively." Another wrote, "Delegation, we tend to work in teams, I assign tasks to subordinates to ensure the work continues.” While one principal stated, "my style and skills as a leader have changed a lot ... my policy is to listen to everyone and be more flexible in making decisions."

The interview data supports principals using a more democratic leadership style, using less micro-management, delegating tasks, giving others responsibilities, listening to their staff, negotiating utilize teamwork and providing opportunities for faculty and staff to be actively involved in the decision-making process. Only two principals said their style has not changed because they have always had a flexible attitude and tend to involve staff in decision-making and solving issues related to school. Several principal comments illustrate this shift; "I use team work, listen to my staff and involve them in the decision making process"; "I work with them as a team"; "twenty percent of decisions are imposed and the rest are decisions coming from them. I have friendly relation with teachers and staff, I listen to their problems and help as much as I can.”

While all the surveyed principals admitted that EFNE led to a change and improvement in their leadership style, the majority of these principals indicated that EFNE also affected their relationship with faculty and staff that is directly linked to their leadership styles. Principal 
responses on questionnaires indicated that $66 \%$ believed that they give more power to their teachers and staff. This included providing teachers with a say in the decision making process, listening more to their teachers and staff, considering their teachers' special circumstances, develop more friendly relationships and spend more time consulting and discussing issues with faculty members. This is illustrated in a statement by a principal, "Yes, the relationship between us (principals and teachers) changed. I started to discuss idea with them, listen to them and consider any circumstances they might have.” Another principal indicated that he "distributed responsibility, giving more power or permission to some of the staff/faculty to make decision, carry out tasks and more responsibility.”

All principals agreed that the reform caused a significant increase in communication with parents. Three principals wrote that there was some exchange of views and decisions with parents and some mentioned parents even help to solve particular problems. However, overall there is still a lack of parental involvement in most schools. Principals indicated that as a result of the reform, they now endure increased pressure from parents. One principal wrote that "parents have become an attack on the leadership and principals take the responsibility of all mistakes" School leaders have to deal with parents who become very demanding and tend to blame the principal for every mistake. Another principal's comment summarizes this thought "parents have become more aggressive with the leadership, blaming principals for all mistakes." Other respondents think that the reform had a positive impact on their relationship with parents. It created more opportunities for communication with parents and allowed for involving them in school activities.

However, interview data indicated that although the reform encourages parental involvement, not many parents are actually involved in the education process. They do not attend meetings in spite of all principals' efforts to attract parents, such as using SMS, phone calls and other forms of communication. Principals argued that parents either resist or refuse to be involved either because they are not interested in their kids' education or are too busy. Some principals said that mothers are more involved than fathers. One principal's comment illustrates this point.

Parents in this area are not very educated, they are not very involved in their kids' education, they are not enough aware of the value of education for their kids so they do not help them much, their academic involvement is missing.

These principals realize the importance of parental involvement when one principal stated, "When parents are involved in some school activities, this has a positive impact on their kids, they are proud of their parents and get more serious and more motivated about their studies, too, but this is very rare." However in the interviews, only one principal admitted that parents were very involved in the school and played a positive role in their kids' education “

\subsubsection{What are the challenges principals face as a result of the reform?}

Analysis of the principals' responses about the challenges that they and their schools face revealed one major challenge, namely, the continuous and sudden changes from the SEC and the unrealistic requirements imposed on schools and teachers from the SEC. One principal 
wrote, "there are lots of changes in roles and policies and they are sudden changes.” There is "continuous adaptation and change of policies made at the level of the SEC." This creates confusion and makes it difficult for schools to cope with and implement policies changes. One of the principals pointed out that the main challenge that his school faces is the "confusion in the offices of the Supreme Education Council and the lack of clarity in planning." Furthermore, several principals indicated that their job is to obey orders. This point was succinctly described by one of the respondents who wrote that there is "control from the Supreme Education Council for everything in schools, and my job is to obey the orders."

Regarding their schools, principals argued that they are hurried to get results from the reform however, they think that it takes time for the reform to develop and results will come later. Schools suffer from a lack of qualified teachers and principals face resistance to change by some parents, teachers and students. As mentioned earlier, several stated that an important challenge is communication with parents and getting them involved in their child's education.

Finally, all principals who responded to the questionnaire were favorable to the move to bilingual (English and Arabic) as the language of instruction providing the following reasons for their support. First, the decision will enable students to understand content better because it is taught in their mother tongue. Second, Arabic is the language of the civilization and culture so students can connect with their identity and country. Third, the change provides students with more trust in themselves and ability to compete with other countries. Finally, it allows parents to follow up on their kids' achievement at school because not all parents speak or read English.

In addition, the majority of participants who were interviewed, ten out of eighteen, were strongly in favor of the move back to Arabic as medium of instruction in content area subjects. They argue that teachers' level of English was not good enough to enable them to teach in English; students, also, did not have the required proficiency in English to enable them to achieve high in content courses. They support bilingualism because even if the textbooks are written in Arabic, the terminology is still in English. Some schools surveyed parents and students and results indicate that both parties favored bilingualism: instruction in Arabic, terminology in English.

In spite of this positive attitude to the use of Arabic in content area courses, some respondents admitted that it was harmful to some students. On respondent stated:

It is much better to go back to the bilingual approach, but we need to go slow . . . many students were hurt by the decision to teach in English. But now, exceptional students, are hurt in the move back to Arabic - they were great students in English and now they are suffering as they move back to Arabic.

Four respondents were more cautious and suggested they should wait to see the results of this practice to express their opinions. Two respondents thought that there should be schools that teach in Arabic and others that teach in English to accommodate the needs of students and to 
offer options for the various types of students. Some parents prefer their children to be taught in English. Only two principals opposed the move because it happened too quickly.

\subsection{Teachers' Perceptions}

Teachers' perceptions of the reform are based on responses to the survey questions that ask about the effect of the reform on them as well as on their students, the challenges they face, and their perceived advantages and disadvantages of EFNE. Additional interview questions that focused on workload, motivation of students and parental involvement provide additional information. Overall $73 \%$ of the teacher respondents indicated a positive view of EFNE. Although many had concerns about the implementation, numerous changes and issues regarding workload and language, there was a large percentage that witnessed the importance of the reform and the early impact on students. Table 5.2 provides a brief overview of the teacher findings followed by specific discussion..

Table 5.2. Brief Summary of Key Teachers' Findings

\begin{tabular}{|c|c|c|}
\hline & Teachers' Questionnaire Findings & Teachers' Interview Findings \\
\hline $\begin{array}{l}\text { Challenges } \\
\text { teachers face } \\
\text { as a result of } \\
\text { the reform. } \\
\text { Advantages } \\
\text { and } \\
\text { Disadvantages }\end{array}$ & $\begin{array}{l}\text { 96\% adapted teaching style: } \\
\text { - New strategies (55\%) } \\
\text { - Integrate technology (40\%) } \\
\text { - Active Learning (20\%) } \\
\text { - Considered student learning } \\
\text { differences (12\%) } \\
\text { The reform affected planning and } \\
\text { preparation } \\
\text { • Better organized (23\%) } \\
\text { • Improved planning (15\%) } \\
\text { Increased workload (28\%) } \\
\text { Lack of motivation of students (51\%) } \\
\text { Student behavioral issues (49\%) } \\
\text { Parents' lack of support (16\%) } \\
\text { 97\% teacher cited advantages to the } \\
\text { reform } \\
\text { - Use of modern instructional } \\
\text { - Strategies (54\%) } \\
\text { - Students benefit (29\%); } \\
\text { 80\% cited Disadvantages } \\
\text { - Reform introduced too hastily } \\
\text { (32\%) } \\
\text { - Increased workload (23\%) } \\
\text { - Long school day (15\%) }\end{array}$ & $\begin{array}{l}\text { - All interviewees agreed } \\
\text { workload was increased } \\
\text { hampering teaching and } \\
\text { affecting personal lives. Type } \\
\text { of work added was provided. } \\
\text { - Specific reasons for lack of } \\
\text { student motivation were } \\
\text { provided. } \\
\text { - Specifics parent Issues } \\
\text { regarding lack of involvement } \\
\text { were provided. }\end{array}$ \\
\hline
\end{tabular}




\subsubsection{What are the effects and impact of EFNE on teachers?}

When asked about the effects of the reform, the large majority of teachers (94\%) declared that the reform impacted their teaching with $96 \%$ stating they had to adapt and develop their teaching style and strategies to meet the requirements of the reform. Responding to what the impact of the reform was on their teaching, one respondent wrote: "it (the reform) affected me positively; I learned new teaching strategies and students became the center in my teaching.” Another respondent sums up this impact quite well stating: I changed my style of teaching by using new methods in education, I increased the creativity in teaching, and I used technology in education. I also used the Internet to search for some information and student-centered lessons."

Teachers declared that the reform has improved the profession mostly concerning teaching methodology. The reform encourages teachers to utilize new teaching methods. Among these participants, $40 \%$ integrate technology, $31 \%$ of the respondents stated they used new teaching strategies, 20\% incorporate "active learning” and 12\% consider individual student differences when planning lessons. The following responses illustrate these changes: "I transformed from a traditional teacher to a modern teacher and the students became the center of the educational process. I also started to use technology in education that improved my teaching and students' learning;" “ I changed my style of teaching by developing student-centered lessons;" "Yes, I changed my style of teaching by using new methods in education, like using the active learning, and activities in the classroom;" and "I am now using different activities that engage students and help them to be active and enhance their learning," and that "Yes, the reform changed my style of teaching to a student-centered education.”

From these comments, it is evident that teachers have changed teaching styles by developing a more student-centered approach, using new teaching strategies including the integration of technology. The learner is now the focus of the learning process. Teachers claim to use activities that engage students, foster student cooperation, and shift attention from a focus on the teacher to emphasize the role of the learner who becomes an active participant in the learning process.

While most teachers hold the view that the reform has positively changed their classroom performance, they were divided in their perception of the impact of the reform on the students. Roughly $55 \%$ of the teachers think the reform had a positive impact on students; $23 \%$ a negative student impact and the remaining $22 \%$ believe that the reform had a limited or weak impact on students. The positives according to these teachers include increased academic abilities and thinking skills (11\%), improved self-confidence, better motivation and an increased interest in school. The negative areas were increased work for students reducing motivation, students developing a negative attitude toward learning and more behavioral issues

Teachers also mentioned that the reform impacted not only on their instruction but also their approach planning and preparation. Twenty-three percent of the teachers stated that their planning is more organized and accurate while $15 \%$ described it as improved. Participants wrote "I learned more about writing the goals and lesson plans;" "I change my planning and 
the preparation for the lessons;" "the improved planning helps me to teach better;" and "Planning takes more time to write it, but it is organized."

In summary, the reform helped to increase teacher willingness to develop professionally, to change their teaching styles and adopt modern instructional strategies and techniques. This is due to the professional development that accompanied the reform and that helped teachers become aware of and able to incorporate new teaching techniques in classroom practices. It also helped some students benefit and improve academically.

\subsubsection{What are the challenges teachers face as a result of the reform?}

When asked about challenges, 95\% of the respondents mentioned several types of challenges that revolve around the following major themes: increased workload 28\%, student issues such as a lack of motivation and behavioral concerns $27 \%$ and the lack of parental support $16 \%$. The major challenge faced by teachers is the increased workload. One of the respondents wrote the "reform implementation is a burden and a time consuming process." Others mentioned that the reform requires them to complete not only their "workload but also too many administrative tasks." Another participant wrote "there is too much work, the school day is very long and teachers are becoming very tired. There is also too much pressure from the Supreme Education Council." These challenges have resulted in "pressure on the teachers" distracting attention from their teaching and keeping up with the additional non-teaching tasks. Some teachers wrote that challenges include an "increase in the burden on the teacher, which led to neglect preparation and focus more on the administrative and secretarial work," and "finding sufficient time to meet all the requirements of reform, under the pressure of teaching and other things on the teacher."

In an effort to follow up some of the issues that emerged on the questionnaires, interviews were used to further discuss the increase in teacher workloads. All of the teachers who were interviewed (26/26) agreed that their workload was significantly increased and this impacted their teaching and personal lives. The first issue deals with the workload and the concern is what type of work has increased and has this hampered teaching? The following responses illustrate the type of work that these teachers are describing.

Lots of paper work, electronic gate Learning Management System. For example, we do our job once like the planning and again reload it on LMS. It takes a lot of time. We are busy all the time as we do the same lesson plan many times like we have to share among our staff, send by email to our coordinators, upload on LMS etc., We also have variety of test analysis, secretarial work and paperwork, it is too much load for a teacher.

These teachers argue that all the time spent on "trivial" things and "paperwork" takes away from planning and other aspects of teaching and as one teacher stated "We are far away from the main purpose, far away from teaching students.”

The second most frequently occurring challenge is student's "bad behavior" and "lack of motivation" that was mentioned by $51 \%$ of the participants who indicated that students issues were a concern. Participants wrote "The students don't respect the rules or follow them," 
there is a lack of motivation by students and this causes more problems that teachers have to address ... like controlling students in the classroom," the students are careless and this leads to bad behavior." Students lack motivation and interest in studying, do not do homework, "lack seriousness about studying” and even "lack respect to the teacher."

Interviews probed about students' lack of motivation as a challenge from the reform and why do student lack motivation. Teachers stated that "the students are not motivated at all. They are just upgraded (passed) each year irrespective of the grades they earn, "The family background is not well educated," "They hardly have any goals in life." The following statement can summarize the major argument put forth for the lack of motivation;

we have students from sound economic backgrounds. They don't need money. In the past, we used to encourage students with some incentives. They had to study to choose respective fields and get good jobs but now they can easily get a job without much education ... Sometimes families and parents don't need anything as their economic status is very high, they think why do they have to work and study.

It is important to note that none of these particular reasons can or were linked directly to the education reform. These problems existed prior to and will probably be evident after the reform has taken roots.

Related to this concern about student misbehavior is some other teachers' (16\%) complaint that parents do not support not only the reform but also education. The written comments "the parents are not supporting the teachers," "parents do not care about education," the parents do not care so the children also do not care" all indicate how some teachers believe that the parents are not supportive of education, teachers and students.

Interviews addressed the lack of parental involvement. These teachers were asked what they did to involve parents and why they thought parental involvement so low. These teachers stated they arranged for parent meetings, called parents, invite parents to observe classes, and developed a parent council. One teacher stated "there are too many invitations sent to parents but rarely they join.” However, the parental involvement is still lacking. The reasons teachers gave for the low involvement is the parents lack of education; some of the parents are not too concerned about their child because their child will be easily hired by government for any job and knowing that they will not be fired; as parents are just too busy; most Qatari students have private tutors and parents are in communication with the tutors; and it is often the maid who is involved in the children's lives.

5.2.3 What are the advantages of the Qatari school reform as perceived by teachers?

When asked about the advantages and disadvantages of the reform, $97 \%$ of the teachers declared it had advantages to the educational reform. Analysis of teachers' responses point to several perceived advantages of the reform that revolve around the theme of improvement of instructional practices and the education system that in turn has benefits for the Qatari society and country. More than $54 \%$ of teachers pointed out that the reform resulted in the use of modern instructional strategies and techniques that are informed by research and that, they believe, are more useful than the traditional methods that were used before the introduction of 
EFNE. Other teachers (29\%) pointed to the important student benefits that include encouraging creativity and innovation, students move involved in the educational process, and the increased use of technology and computers.

Additional advantages included "development student critical thinking and creativity," "helps them to become faster learners," and increases student independence and autonomy both inside and outside the classroom. Finally, nine percent of the teachers argued that the reform contributes to the progress of the country, improving the education system that allows Qatar to keep pace up international developments around the world and now "Qatar can compete with the education in the modern countries." These respondents seem to be convinced that the reform is helping to achieve one of its major goals, namely, to establish an effective education system that will create change in society, which in turn, will help to achieve the vision of Qatar for 2030.

\subsubsection{What are the disadvantages of the Qatari school reform as perceived by teachers?}

Roughly $80 \%$ of the teachers declared that the reform have disadvantages. The disadvantages centered on three issues: increased workload (23\%), Curriculum issues (15\%) and a long school day (15\%). Regarding the workload, teachers wrote, the "the workload is huge ... the paper work is too much" and "disadvantages such as the huge amount of administrative work and the huge amount of classroom work which causes stress for the teacher.” The curriculum according to these teachers is "long and the time is not enough to finish the work," "the curriculum level is high for the students" and there is "too much content to cover."

Another disadvantage that was highlighted by 32\% of the teachers is that the reform has been introduced too hastily and the SEC wants results too quickly. For instance, one teacher declared that the "it takes a long time to see big results from all these changes." Finally one respondent recommended, "the reform should be brought about more gradually" supporting other teachers' opinions. One of the respondents' quote sums up this disadvantages and describes their effect on the teachers, "Yes, the reform has disadvantages like the disintegration of the family because of the burdens of their (teachers) job, the school homework, the administrative work, professional development and the long school day."

Similar to the principals' responses in this study regarding the move to bilingual language of instruction, $82 \%$ of the teachers thought this was the right decision with $47 \%$ citing Arabic as the mother tongue of the nation, $19 \%$ believe that students must be able to learn in both English and Arabic, 13\% argued that if Arabic is part of the language of instruction students will learn more and 6\% argued that the language of the Quran must be included in the independent schools.

In summary, the teachers' perspective on the reform states that it has helped practitioners to improve their daily instructional practices including the integration of technology. These responses also indicated that the reform has improved students' thinking abilities but also there is a great deal of knowledge to be covered. The decision to move back to a bilingual approach to education was applauded and overall what teachers have learned and experienced from the reform has greatly shaped their view of teaching, students and the classroom in a positive manner. 


\subsection{Parents' Perceptions}

Similar to teachers, parents' perceptions of the reform are based on responses to the survey questions that ask about the effect of the reform on them as parents as well as on their children, the challenges they face, and their perceived advantages and disadvantages of EFNE. Additional interview questions focused on their involvement in their child's education, communication and their comfort with the school and if they needed additional help to academically support their child. Table 5.3 provides a brief overview of the findings followed by an in-depth discussion.

Table 5.3 Brief Summary of Key Parents’ Findings

\begin{tabular}{|c|c|c|}
\hline & Parents’ Questionnaire Findings & Parents' Interview Findings \\
\hline $\begin{array}{l}\text { Challenges } \\
\text { parents face as } \\
\text { a result of the } \\
\text { reform. } \\
\text { Advantages } \\
\text { and } \\
\text { Disadvantages }\end{array}$ & $\begin{array}{l}\text { - Parents believe the reform had a } \\
\text { positive effect on both parent and } \\
\text { child (54\%) } \\
\text { - Parents believe the reform had a } \\
\text { positive effect on both parent and } \\
\text { child ( } 30 \%) \\
\text { - Issues related to curriculum (29\%) } \\
\text { Parents lack ability to help students } \\
\text { (14\%) } \\
\text { - Too much homework (11\%) } \\
\text { - } 61 \% \text { of parents cited advantages } \\
\text { and } 39 \% \text { cited disadvantages. } \\
\text { - Advantages include: improve } \\
\text { learning and thinking skills (24\%) } \\
\text { and improved teaching (22\%) } \\
\text { - Disadvantages include: difficult } \\
\text { curriculum (21\%); concerns about } \\
\text { teachers (19\%); Pressure on } \\
\text { Students (10\%) }\end{array}$ & $\begin{array}{l}\text { - } 68 \% \text { of the parents stated } \\
\text { they were involved in their } \\
\text { child's education and } \\
\text { discussed what that involves. } \\
\text { - } 54 \% \text { of the parents believed } \\
\text { that the schools provided } \\
\text { opportunities for their } \\
\text { involvement. } \\
\text { - } 74 \% \text { of parents indicated that } \\
\text { they are comfortable in the } \\
\text { school } \\
66 \% \text { of the parents believe } \\
\text { their child is a "better" } \\
\text { thinker } \\
\text { Parents were less reliance on } \\
\text { private tutors than before the } \\
\text { shift to a bi-lingual approach } \\
\text { to education }\end{array}$ \\
\hline
\end{tabular}

5.3.1 What are the effects and impact of EFNE on teachers and students?

Overall, $84 \%$ of the parents completing the questionnaire indicated that the reform had some effect. Parents were divided in their opinions about how the reform affected them and their children with a little over half of the surveyed (54\%) parents thought that the reform had a positive effect on both parties, while 30\% thought that it affected them negatively. The remaining $16 \%$ of parents argued that they saw no changes as a result of EFNE.

5.3.2 What are the challenges parents and students face as a result of the reform?

Parents stated that they and their child faced several challenges because of EFNE. The first challenge mentioned by $29 \%$ of the participants centered on issues of curriculum. These parents believe that "the curriculum is difficult for the students and very hard to understand," and that "the focus is on increasing the quantity of knowledge at the expense of quality." The 
key issue is that because the curriculum and homework is difficult, this impacts their role as parents.

Second, parents (14\%) struggled with their own ability to help their students. Several parents stated "I am trying my best to help my children," "I started searching for magazines to find scientific information and knowledge to assist in the discussion with my child," and "it is difficult in understanding what my son says he is studying in school." Parents indicated that since the introduction of the reform, the amount of time parents must spend helping their children complete the work has increased considerably. One parent wrote, I spend "most of my time helping with homework, following up with my kids at home, finding tutors and learning resources.

Finally, 11\% of the respondents stated that EFNE has influenced them as parents and their children through the amount of homework now required of their children and the lack of time the students have to complete all the work. Parents stated there were too many assignments, too much content and too much homework and this increased the burden of studying on the student. One parent stated, "my daughter has trouble understanding the huge amount of information she is given. As these responses indicate, students have had much more homework since EFNE began and this has implications for not only the student but also the parents.

5.3.3 What are the advantages of the Qatari school reform as perceived by parents?

Parents were asked how EFNE has affected themselves and their children and the majority of the parents indicated that the reform had both advantages and disadvantages. The advantages will be addressed first. From the parents' survey responses, $61 \%$ of those parents surveyed believed that the reform had advantages. There were two advantages that were dominant in their responses.

Parents stated (24\%) that there is improved learning and thinking skills and that their child was "learning better." Parents stated that they believe "students gain a tremendous amount of information and seriousness in studying;" "more student thinking and creativity . . . mental capacity development;” and "the emergence of creative, smart and talented students.”

Another stated advantage of the reform is an improvement in teaching instructional methods. It was clear to $22 \%$ of parents that the reform improved teaching. On parent stated that "teaching methods that encourage using thinking and creativity" were being used. One of the parents stated "the teachers are doing better, the students have more quizzes and tests, there is more encouragement for students and there teachers use more interesting and updaed methods of teaching." While these responses point to the parents' awareness of a general improvement at the level of instructional methodology, increase in the knowledge learned, the improvment thinking skills and improved student assessment and curriculum, and differentiated instruction. Nevertheless, they still believe that the reform has some limitations. 
5.3.4 What are the disadvantages of the Qatari school reform as perceived by parents?

Parents listed the difficulty of the curriculum (21\%), teachers' concerns (19\%) and pressure on parents, students and teachers (10\%) as some of the disadvantages of EFNE. First, parents demonstrated a concern that the "curriculum is higher than the level of students" and "the students need longer to learn the curriculum because it is difficult and it takes time for the student and the parents to get used to it." Second, parents thought that one disadvantage of the reform is that the high expectations and standards set for teachers required by EFNE created a large number of teachers who are unqualified. Recent statistics support the accuracy of this parental perception of the current teaching force. As previously mentioned above and worth repeating, more than 30\% of school teachers in Qatar are not qualified to teach, 31\% of teachers in Qatar have no formal qualifications to teach, 35\% of whom are teaching in Independent schools. Also included in parental concerns about teachers is the "instability of teachers" or rather "the high mobility of teachers (who change schools too frequently and even leave the country)" seems to be one of the reasons parents are discontent with the reform. Finally, the lack of Qatari teachers was rightfully mentioned by some participants because there are only 25\% of teachers in Independent schools are Qataris.

Another disadvantage reported by parents was the added pressure on parents, teachers and children. This was only mentioned by $10 \%$ of the parents. One parent wrote, "It (the reform) has a negative impact because it increases the pressure on the student and teacher and parents." These parents believed that the pressure for students was on studying and "knowing so much information" and the pressure for teachers was to "be better at teaching." Parental pressure included following-up on students, "keeping track that students do the increased work," and helping students deal with the added stress.

Similar to the principals and teachers, parents are in full support of the decision to move to bilingual education with $91 \%$ commenting that this was a positive decision. Regarding the parents, $43 \%$ of the respondents expressed that Arabic preserved the mother tongue and 13\% stated that Arabic is the language of the Quran and must be included in education. One parent wrote, "moving back to bilingual is the right decision, learning in Arabic means belonging. It is also the language of the Quran.” Four percent of the parents believed that the curriculum is now easier and the students will learn. One statement expresses this concern "the curriculum has become easier on the child because it is the native language of the student. This means that the student will understand what he/she studied." Finally, there were a few parents who believed that Independent schools should not neglect English, that science and math should be in English and that in order to study outside Qatar, the students will need English.

\subsubsection{Parent Interview data}

There were 50 parents (39 mothers and 11 fathers) interviewed in order to follow up on several issues that needed clarity. The educational background of these parents are as follows: one PhD., three with Post- bachelor Diploma, 22 bachelor degrees, 13 high school degrees, eight completely preparatory school and there were three with a primary school education. The areas addressed included if parents were involved in their child's education and how; what specific actions do schools do to promote their involvement; if parents are comfortable 
going to schools; what parents might need to aid their involvement in their children's' education; to determine if they still are seeking help from tutors since their was a shift back to bilingual education; and to have parents provide their viewpoint "regarding their children as better thinkers since the reform was implemented”.

First, $68 \%$ of the parents interviewed stated they were involved in their child's education. Involvement for these parents can be defined as attending parent meetings $80 \%$, helping with homework 35\%, attending school parties 15\%, observing lessons throughout a school day $15 \%$ and to parents who attended school offered workshops and seminars based on "educating parents about the student's future," and "helping parents to teach their children and how to deal with teenagers in the right way."

Second, 54\% of the parents interviewed believed that the schools requested them to be involved and provided opportunities for their involvement while the remaining $46 \%$ stated that schools did little to involve them beyond parent meetings. Those who thought that the schools involved them provided various examples of ways that the schools provided parental involvement opportunities. These included, workshops and seminars on various topics such as e-learning, addressing problems that students might face, how to deal with your children and advice about academic level of students, ways to teach your children at home, and many invitations to attend class with their children and see how the teachers are teaching. One parent stated schools "invite parents to seminars and workshops about the right ways of teaching students at home, which can lead to a strong relation between the school and home and between student and teachers.”

Third, 74\% of parents interviewed indicated that they are comfortable in the school and felt welcome. Those parents who perceived the schools as unwelcoming made statements that centered on a particular situation or teacher rather than the school itself. However, these parents believe that the school is responsible for all teachers and must continue to work at building relations with parents. Regarding parent-school relations, 26\% of the parents interviewed mentioned continuing to improve communication between schools and parents. Parents suggested to continue providing workshops and seminars (18\%), 10\% desire that schools should involve parents beyond working with student at home, continue to invite parents to school to see teachers and so they can better understand school and the educational level of their child, and a few parents thought that they should be involved in curriculum preparation by taking suggestions from parents and involving the parents in all things related to the student in terms of education.

Fourth, these parents indicated that they are still relying on private tutors to help their students. However, their comments indicated that there seems to be somewhat less reliance on private tutors than previously before the shift to a bi-lingual approach to education. On parent wrote, "there is no need for a private tutor now especially for English" while another parent provides an opposite perspective by stating "my child's academic level needs private teacher but the family budget could not afford it. The price for the private teachers are so expensive, these days a lesson for 1 hour is 150 QR and more some will be 250 QR.” 
Although both perceptions are evident, the majority of parent interviewed indicated that tutoring was not as big of an issue since the movement to bilingual education.

Finally, $66 \%$ of the parents interviewed believe that their child is a "better" thinker supporting the $24 \%$ of the parents surveyed who stated that there was an increase in learning and thinking. The interviewed parents made statements that illustrate this belief. For example, one parents stated that her daughter "adopted some ideas and opinions that she can discuss ... she is more dependent on herself in many school activities \& research.” Another parent stated her daughter is "better in thinking and depends on herself because the education system requires her to have her own opinion, support it with evidence and defends that opinion.” Others argued that EFNE gets students to "try to find answer not like the old system of memorizing" and EFNE encourages students to "discuss with students their age from other countries like Saudi Arabia \& Kuwait because Education is developed a lot here in Qatar.”

\section{Discussion}

These findings provide valuable insight from stakeholders regarding Qatar's educational reform. As expected, there are both positive and negative aspects of the reform reported by principals, teachers and parents. Overall, principals were positive about the reform, with a realization that their role is more complex with much more responsibilities and that the reform demanded them to adapt their leadership styles. From surveys and interviews, it seems that EFNE has had a positive effect on principals. Principals indicated they use less micro-management and more delegation of responsibilities with an emphasis on more communication with faculty. The reform has caused more intentional efforts to increase in communication with and involvement of parents. However, the continuous and sudden changes and unrealistic requirements imposed on schools and teachers from the SEC are problematic. More importantly, the impatience from the SEC and others has added pressure and forces principals to rush to get evidence of results, although it takes time for the reform to develop. Still the lack of qualified teachers is hampering the development of the reform.

The shift in principals' leadership styles is vital for successful educational reform to develop and mature. It seems that these principals are adapting their leadership style to various situations that arise and this is important for this flexibility when dealing with the many changes that reform brings. In addition, despite the overwhelming support for the value of parent involvement in education and school reform, Gonzalez-DeHass and Willems (2003) point out "parent involvement is underutilized at all levels, while parental participation at high school levels is particularly low" (p. 86). Independent school principals and teachers need to identify and examine some of the barriers that prevent parental involvement and then utilize this information to involve parents in order to benefit the school and education of students. More importantly, principals, teachers and parents need to develop a common definition and expectations of what it means to be involved in a child's education. Principals should be more diligent about informing parents about the reform, providing answers to their many questions and discussion about expectations would prove useful. Furthermore, possibly offering workshops for parents regarding how to support their children would aid in their 
child's academic success in the midst of educational reform. This requires time and possibly shifts in culture and beliefs, but this is well worth the efforts in order to aid in the success of EFNE.

Three quarters of the teachers hold a positive view of the reform and this is clearly reflected in the changes in teaching and the classroom. Teachers are using innovative teaching strategies, integrating technology in their teaching, incorporating active learning and considering the individual student differences when planning. Planning and lesson preparation have improved becoming more organized and accurate. These findings also raise concerns that need serious consideration. First and foremost is the large amount of extra work and effort incurred by ENFE. This concern was expressed by teachers and should be considered in the revision of the reform. Not that increasing the workload of teachers is a problem because that is expected during educational reform. The concern is the type of work added is problematic. Trivial assignments, paperwork that seems meaningless and other work that seems to serve little purpose needs to be curbed so that teacher still have the time needed to plan and teach. This addition of seemingly meaningless work could be the reason some stakeholders feel frustration with the reform and the cause of their resistance to it. As with principals, teachers argued that reform takes time and although EFNE is very ambitious, change should be introduced slowly and patience is needed for results. In addition, they seemed concerned with the lack of parental support and involvement but applauded the shift back to bilingual education.

Another important point is that teachers who are surveyed and interviewed often use education jargon to describe what is happening in their classes. Terms such as student-centered, differentiation and cooperative learning are often part of their discourse as they describe their experiences with the reform. However, we can only assume that how they describe their teaching occurs in their classroom and teachers' claims might not truly reflect what is occurring in classrooms. There would need to be classroom observations added to future research studies to determine the true impact of educational reform on these teachers.

There were a little over half parents thought that the reform had a positive effect although parents and students faced challenges including the difficulty of the curriculum, parents limited ability to help their children and the increase pressure and homework load on students. However, parents believed that there was an increase in learning and improvement in thinking; teaching was improved and parent are still using private tutors however there seems to be some reduction and less reliance on tutors than before the shift to bilingual instruction. Most parents believed they were involved in their child's education and felt comfortable working and communicating with schools.

Finally, as previously touched on above, the data gathered in this study is through surveys and interviews and is self-reported by the key stakeholders in Qatar. The limitation is that the research only provides respondents' written and verbal descriptions of their perceptions. These responses should not be taken as a totally accurate description of what the respondents actually do or think. Also, the open-ended questionnaire can often represent an over simplification of reality of the studied context. Nevertheless, this research provides a 
snapshot of the stakeholders' perceptions and provides valuable insights into Qatar's education reform EFNE that can be beneficial to those involved in educational reform.

\section{Conclusion}

This study provides valuable insight for those involved in Qatar's EFNE. First, these findings are context based and with any analysis of an educational reform, the stakeholders' experiences with the reform, is greatly shaped by the particular school. Stakeholder's perceptions can vary greatly form one school to another. Nevertheless, these findings indicate that EFNE has provided several educational improvements evident in these principals'; teachers' and parents' reported perceptions.

Second, although the reform is perceived to have positive effects, it is a long and difficult process that requires patience. These participants are struggling to meet the requirements of the reform and implement the needed changes. EFNE is difficult, placing pressure on the teachers, school leaders and parents and requiring them to do tasks that they are not ready to fulfill, or do not have the skill to prove successful. It would be valuable to compare these results to the other Independent school cohorts.

Third, Steiner-Khamsi (2004) makes an interesting and relevant point for concerning reform. That is, "a history of skepticism has led to numerous warnings being issued regarding the transferring, borrowing and lending of educational policies and programs. Whether the educational transfer is whole, selective or eclectic, the transfer isolates 'education from its political, economic, and cultural context (Steiner-Khamsi, 2004, p. 201). This is vital for EFNE. Since EFNE is close to a decade old, it is time for the decision makers and the SEC to move away from relying on expertise and models designed by and for Western countries and start building up their own expert contingents by encouraging local expertise and educators with better knowledge of and experience in the local context to develop and evaluate EFNE that takes into account the political, economic, social, and cultural factors. Qatar needs to develop and implement their own unique reform model that meet their learners' needs and is appropriate to administrators, teachers, parents, students and the local community.

Finally, underlying successful educational reform is the support of all stakeholders in education. It would be wise for the architects of the reform and those in charge of its implementation to examine the perceptions of the issues that have emerged in this study and consider the role all stakeholders have in educational reform in Qatar.

\section{Acknowledgement}

A Qatar Foundation’s National Priorities Research Program Grant No. 42055033 has funded this research. 


\section{References}

Adams, P., \& O’Neill, J. (2010). Heeding parents in educational reform. New Zealand Journal of Teachers' Work, 7(1), 1-2.

Bailey, B. (2000). The Impact of Mandated Change on Teachers. In B. Nina \& A. Hargreaves (Eds.) The Sharp Edge of Educational Change: Teaching, Leading, and the Realities. New York: Routledge and Falmer.

Bogdan, R. C., \& Biklen, S. K. (2002). Qualitative research for education: An introduction to theory and methods (4th ed.). Needham Heights, MA: Allyn and Bacon.

Brewer, D. J., Augustine, C. H., Zellman, G. L., Ryan, G. W., Goldman, C. A., Stasz, C., \& Constant, L. (2007). Education for a new era: Design and implementation of k-12 education reform in Qatar. Rand Corp: Santa Monica, CA. Retrieved from http://www.rand.org/pubs/monographs/MG548/ (February, 2013).

Carless, D. R. (2001). A Case Study of Curriculum Implementation in Hong Kong. In D. R. Hall \& A. Hewings (Eds.), Innovation in English language teaching: A Reader, pp. 263274. London: Routledge in association with Macquarie University and The Open University.

Christenson, S. L., \& Anderson, A. R. (2002). Commentary: The centrality of the learning context for students' academic enabler skills. School Psychology Review, 31, 378-393.

Cohen, L., Manion, L., \& Morrison, K. (2007). Research Methods in Education (6th ed). Oxford, UK: Routledge Publishers.

Darling-Hammond, L. (1997). The right to learn: A blueprint for creating schools that work. San Francisco: Jossey-Bass.

Fullan, M. (2011, May). Choosing the wrong drivers for whole system reform. (Seminar Series Paper No. 204). Melbourne, Australia: Centre for Strategic Education.

Fullan, M. (2005). The Meaning of Educational Change : A Quarter of a Century of Learning, pp. 202-216.

Fullan, M. (2001). The new meaning of educational change (3rd ed.). New York: Teachers College Press.

Fullan, M. (2000). The three stories of education reform. Kappan Professional Journal, 81(8), 581-584.

Fullan, M. G., \& Miles, M. B. (1992). Getting Reform Right: What Works and What Doesn't. Phi Delta Kappan, 73(10), 745-749.

Gonzalez-DeHass, A. R., \& Willems, P. P. (2003). Examining the underutilization of involvement in the schools. The School Community Journal, 13(1), 85-99.

Hargreaves, A., Earl, L., Moore, S., \& Manning, S. (2001). Learning to change Teaching beyond subjects and standards. San Francisco: Jossey-Bass. 
Hargreaves, A., \& Fullan, M. (1998). What's worth fighting for out there? New York: Teachers' College Press.

Hargreaves, A., \& Goodson, I. F. (1996). Teachers' Professional Lives. New York: Routledge.

Healey, H., \& DeStefano, J. (1997). Education reform support: A framework for scaling up school reform. Denver, CO: Research Triangle Institute. Retrieved from http://www.rti.org/publications/abstract.cfm?pubid=1370 (January, 2013).

Henderson, A. T., \& Mapp, K. L. (2002). A new wave of evidence: The impact of school, family, and community connections on student achievement. Austin, TX: Southwest Educational Development Laboratory.

Houston, Paul D. (1998). The ABC's of Administrative Shortages. Education Week. June 3, 1998.

Lewis, A. C., \& Henderson, A. T. (1997). Urgent message: Families crucial to school reform. Washington, DC: Center for Law and Education.

Kezar, A. (2005). Consequences of radical change in governance: A grounded theory approach. Journal of Higher Education, 76(6), 634-635.

Kilgallon, P., Maloney, C., \& Lock, G. (2008). Early Childhood Teachers Coping with Educational Change. Australian Journal of Early Childhood, 33(1), 23+.

Kirk, D. J., \& Jones, T. C. (2004). Effective schools. Dallas, TX: Pearson Education. Retrieved from http://www.pearsonassessments.com/NR/rdonlyres/AE0CB466-32E1-4CDD-8B64-11A 595251F7A/0/EffectiveSchools_Final.pdf (January, 2013).

Kirk. D., \& Macdonald, D. (2001). Teacher voice and ownership of curriculum change. Curriculum Studies, 33(5), 551-567.

Lamie, J.M. (2005). Evaluating changes in English language teaching. London: Palgrave Macmillan.

Lieberman, A., \& Pointer-Mace, D. H. (2008). Teacher learning: The key to educational reform. Journal of Teacher Education, 59(3), 226-234.

Lieberman, A. (1997). Navigating the four C's: Building a bridge over troubled waters. In D.J. Flinders \& S.J. Thornton, (Eds). The curriculum studies reader, pp. 350-354. New York: Routledge.

Leithwood, K, Seashore Louis, K. S., Anderson, S., \& Wahlstrom, K. (2004). Review of research: How leadership influences student learning. The Wallace Foundation. Retrieved from http://mt.educarchile.cl/MT/jjbrunner/archives/libros/Leadership.pdf (January, 2013).

Lewis, A. C., \& Henderson, A. T. (1997). Urgent message: Families crucial to school reform. 
Washington, DC: Center for Law and Education. Retrieved from http://www.familyimpactseminars.org/s_wifis11c03.pdf (February, 2013).

Margolis, J., \& Nagel, L. (2006). Education reform and the role of administrators in mediating teacher stress. Teacher Education Quarterly, 33(4), 143-159. Retrieved from: http://www.teqjournal.org/backvols/2006/33_4/21margolis\%26nagel.pdf (February, 2013).

Markee, N. (1997). Managing curricular innovation. Cambridge, England: Cambridge University Press.

Matthews, L. J., \& Crow, G. M. (2003). Being and becoming a principal: Role concepts for contemporary principals and assistant principals. Boston, MA: Allyn and Bacon.

Newmann, F. M., \& Wehlage, G. G. (1995). Successful school restructuring: A report to the public and educators by the center on organization and restructuring of schools. Madison, WI: Center on Organization and Restructuring of Schools, University of Wisconsin-Madison. Retrieved from: http://www.wcer.wisc.edu/archive/cors/Successful_School_Restruct.html_ (March, 2013).

Nunan, D. (2003). The impact of English as a global language on educational policies and practices in the Asia-Pacific region. TESOL Quarterly, 37(4), 589-613.

Rea-Dickens, P., \& K.P. Germaine, (Eds). (1998). Managing evaluation and innovation in language teaching: Building bridges. London: Longman.

Sambidge, A. (2010). Expat workers to drive Qatar population growth. Arabian Business. Retrieved from: http://www.arabianbusiness.com/expat-workers-drive-qatar-population-growth-304109. html (March, 2013).

Sammons, P. (1999). School Effectiveness. The Netherlands: Swetz and Zeitlinger.

Schweisfurth, M. (2002). Teachers, democratization and educational reform in Russia and South Africa. Providence, RI: Symposium Books.

Social \& Economic Survey Research Institute (2011). Education in Qatar: Parent Satisfaction, Tutoring Demand, School Choice and Coed Schooling, Executive Summary Report. Doha, Qatar. Retrieved from: http://cisco.qu.edu.qa/sesri/documents/omnibus_education_report_v3_JWcomments_1_ pdf (January, 2013).

Sofaer, S. (1999). Qualitative methods: What are they and why use them? Health Service Research, 34(5), 1101-1118.

Steiner-Khamsi, G. (2004). Blazing a trail for policy theory and practice. In G. Steiner-Khamsi (Ed), The global politics of educational borrowing \& lending, pp. 201-220. New York: Teachers College Press. 
Strauss, A., \& Corbin, J. (1998). Basics of qualitative research: Techniques and procedures for developing grounded theory (2nd ed.). Thousand Oaks, CA: Sage.

Supreme Education Council (2012a). Independent Schools. Retrieved from: http://www.sec.gov.qa/En/pages/Glossary.aspx (March 2013).

Supreme Education Council (2011). Above 30 \% teachers not qualified. Retrieved from: http://www.thepeninsulaqatar.com/qatar/163929-above-30pc-teachers-not-qualified.html (December, 2012).

Troudi, S, \& Alwan, F (2010). Teachers' feelings during curriculum change in the United Arab Emirates: Opening Pandora's box. Teacher Development, 14(1), 107-121.

\section{Note}

Note 1. A Cohort is group of Independent schools that opened in a particular year. For example, Cohort 1 contained 12 schools that opened in 2004. For a list of Independent schools in Qatar see:

http://www.sec.gov.qa/En/ServicesCenter/Pages/QatariSchoolsListing.aspx

\section{Copyright Disclaimer}

Copyright reserved by the author(s).

This article is an open-access article distributed under the terms and conditions of the Creative Commons Attribution license (http://creativecommons.org/licenses/by/3.0/). 